\title{
On Norman Geschwind's Facility with Languages
}

\author{
Victor W. Mark
}

Received: 14 June 2010 / Accepted: 8 August 2010 / Published online: 21 August 2010

(C) Springer Science+Business Media, LLC 2010

I read with great interest Michael Geschwind's reflections on Norman Geschwind, his distinguished cousin and pioneer of American behavioral neurology, in the June issue of Neuropsychology Review on disconnection syndromes. I myself, like so many other neurologists, was a disciple or co-worker of several trainees of the late Dr. Geschwind (Drs. Heilman, Ross, and Brown), which naturally greatly influenced much of my career path and neurological perspective.

I would like to comment on Norman Geschwind's facility with so many languages, which Michael Geschwind indicated. While I was in the Behavioral Neurology research fellowship program of Dr. Kenneth Heilman at the University of Florida in the 1980s, I lamented my inability to understand what had been reported in a good many legacy foreign case reports, and I admired how Norman Geschwind could make sense of these. My cofellow, Carol Kooistra, reacted to my despair by simply saying, "So why don't you read them?" She pointed out that with a dictionary and a basic understanding of the grammatical rules from the language in question, one could access the foreign literature reasonably well.
I already had a working knowledge of basic German from high school. Soon I signed up for French classes at night. Before too long, I was reading Dejerine, Wernicke, and so on. I labored over my translations, which I keep to this day. As indicated by Michael Geschwind, I too found that the details of these classic works were mostly unknown to American neurologists, and it was a thrill to read and dissect original case reports from a century earlier. In my own publications, as much as I can, I cite the original foreign-language version of a paper rather than a translated citation or a second-hand reference to that work. To this day, when something interests me in German or French neurology publications (and to a lesser extent Italian or Spanish), I will get busy translating. (I will even go so far as to arrange for colleagues, when possible, to translate for me from Japanese, Russian, or Polish case studies.) To be sure, I am probably incorrect about some of my renderings, but I would rather have partial insight than none at all.

Norman Geschwind's example in this regard strongly influenced me. I hope that we American neurologists never fail to learn, and always want to learn, from landmark case studies from other countries.

\footnotetext{
V. W. Mark $(\bowtie)$

University of Alabama at Birmingham,

Birmingham, AL, USA

e-mail: vwmark@uab.edu
} 